\title{
Why Tree analysis to find the root cause of environmental problem (case study on geothermal power plant)
}

\author{
Suyud Warno Utomo $^{1}$, Raity Arief Hidajat $^{2,}$, and Iwa Garniwa ${ }^{3}$ \\ ${ }^{1}$ School of Environmental Science, Universitas Indonesia and \\ Department of Environmental Health, Faculty of Public Health, Universitas Indonesia \\ ${ }^{2}$ School of Environmental Science, Universitas Indonesia \\ ${ }^{3}$ Department of Electrical Engineering, Faculty of Engineering, Universitas Indonesia
}

\begin{abstract}
Concept of sustainable development were introduced in 1987 by the world commission on environment and development, chaired by Gro Harlem Bruntland. Sustainable development is a development process that is principled to meet the needs of the present without compromising with the risk of fulfilment of the needs for future generations. Challenges that must be faced in order to achieve sustainable development is how to repair the environmental destruction without compromising the need for economic development and social justice. The 2005 World Summit outlined sustainable development consisting of three main pillars, includes economic, social and environmental interdependence and strengthening. Environmental aspects sometimes having problems either because they are directly caused by human error or mismanagement. Root cause analysis method is needed to find out the contributing factor of the problems. In this research, Why Tree method is used along with the RCA-Constructor software to investigate the root cause of geothermal power plant's environmental problems in Indonesia. This finding is expected to formulate appropriate and continuous improvement steps to prevent the similar events in the future.
\end{abstract}

\section{Introduction}

The need for electricity continues to increase along with the increase in population, technology and the level of economic growth of the community caused the construction of many power plants to meet the electricity needs. However, the construction of big power plant creates side impact to the environment.

Electricity is a very important source of energy today. Data from United Nations Sustainable Development Goals [3] shows that energy is the dominant contributor to climate change, where it around $60 \%$ of the total of global greenhouse gas emissions. Indoor air pollution from combustible fuels for household energy caused 4,3 million deaths

\footnotetext{
* Corresponding author: raity.arief@gmail.com
} 
in 2012, with women and girls accounting for 6 out of every 10 of these. However, the renewable energy used in global energy consumption has only reached $17.5 \%$ in 2015 .

On 1987 the the world commission on environment and development chaired by Gro Harlem Bruntland has been introduced the concept of sustainable development. Sustainable development based on United Nations Sustainable Development Goals (SDGs) is a development process that is to meet the needs of the present without compromising the fulfilment of the needs of future generations. The factor that to achieve sustainable development is how to repair the destruction of the environment without compromising the need for economic development and social justice [3, 4].

One of renewable energy source and clean is geothermal. Indonesia has great potential geothermal sources. Based on data from the Geological Agency, Ministry of Energy and Mineral Resources, there were at least 331 geothermal energy source locations arround Indonesia on 2016. The electrical potential that can be raised reaches 28,579 MWe with details of 11,073 MWe and estimated reserves around 17,506 MWe and installed capacity of 1,534 MWe [5].

Geothermal power plants known as environmentally friendly power plants, like other power plant from the source of photovoltaic and wind that produces less air pollution compared to using fuel oil. Land use for geothermal power plants also smaller per megawatt compare to other types of power plants $[6,7]$.

Table 1. Geothermal data in Indonesia

\begin{tabular}{|l|r|r|r|}
\hline \multicolumn{1}{|c|}{ Location(s) } & \multicolumn{1}{c|}{$\begin{array}{c}\text { Resource } \\
\text { (MWe) }\end{array}$} & $\begin{array}{c}\text { Reserve } \\
\text { (MWe) }\end{array}$ & \multicolumn{1}{c|}{$\begin{array}{c}\text { Installed } \\
\text { (MWe) }\end{array}$} \\
\hline Sumatra & 4,818 & 6,944 & 177 \\
\hline Java & 3,099 & 7,187 & 1,224 \\
\hline Southeast Bali & 726 & 1,125 & 12,5 \\
\hline Kalimantan & 169 & 13 & - \\
\hline Sulawesi & 1,535 & 1,462 & 120 \\
\hline Maluku & 651 & 775 & - \\
\hline Papua & 75 & - & - \\
\hline & $\mathbf{1 1 , 0 7 3}$ & $\mathbf{1 7 , 5 0 6}$ & $\mathbf{1 , 5 3 3 , 5}$ \\
\hline
\end{tabular}

In the operation of geothermal power plants in Indonesia which are generally located in the forest and plantation areas, sometimes there are problems that cause environmental impacts such as landslides which impacts on decreasing river water quality and damage the rice fields and plantations of the community. This environmental problem must be avoided because it is not complying with government regulations and the resulting impact will harm the environment and human life. By knowing the cause of the problem to the environment, appropriate preventive and corrective actions can be taken to prevent the same event from happening in the future. The goal of the investigation system is to work through all causes, including physical, human and system-level, to find and eliminate all root causes of the events to prevent the incident from reoccurring.

The purpose of this research is to establish a Root Cause Analysis (RCA) to find the basic problems of an event that causes an impact on the environment. The case raised in this research is about a root cause analysis of landslide at a geothermal power plant area.

\section{Methodology}

The methodology used in this investigation for root cause analysis is Why Tree [2]. The Why Tree analysis can be used on all levels of events, but primarily on complex events. Why Tree is conducted with use of RCA-Constructor software to create and accelerate the process of Why Tree analysis. This software produces boxes on the structure of Why Tree analysis to find the root cause more effective. Why Tree analysis use "cause and effect 
tree" and it is recommend to build the Why Tree first for the better display of interactions of causes.

The case of environmental problems analysed by the Why Tree analysis method is a landslide event in the area of a geothermal power plant in the province of West Java. The landslide hit a community field which caused flooding and damage to the community rice field.

To start Why Tree analysis, data is collected either through interviews, work records, protective system analysis and other data records to make a sequent of event before, during and after the event, from hour to hour to make it easier when construct the Why Tree. The based theory underlying of the direct cause of the event is very important to know and analyse the physical cause of the event. Based on the case of a landslide in Asia, the theory underlying the cause of the landslide [12] commonly caused by:

- Erosion

- Earthquake

- Change of terrain contour

- Water spring

- Manifest crater

- Soil saturation

Of the 6 causes immediately derived again by analysing them based on existing event data to find out the cause by asking "Why". The causes are generally in the form of human cause or human error and it caused by the system failure.

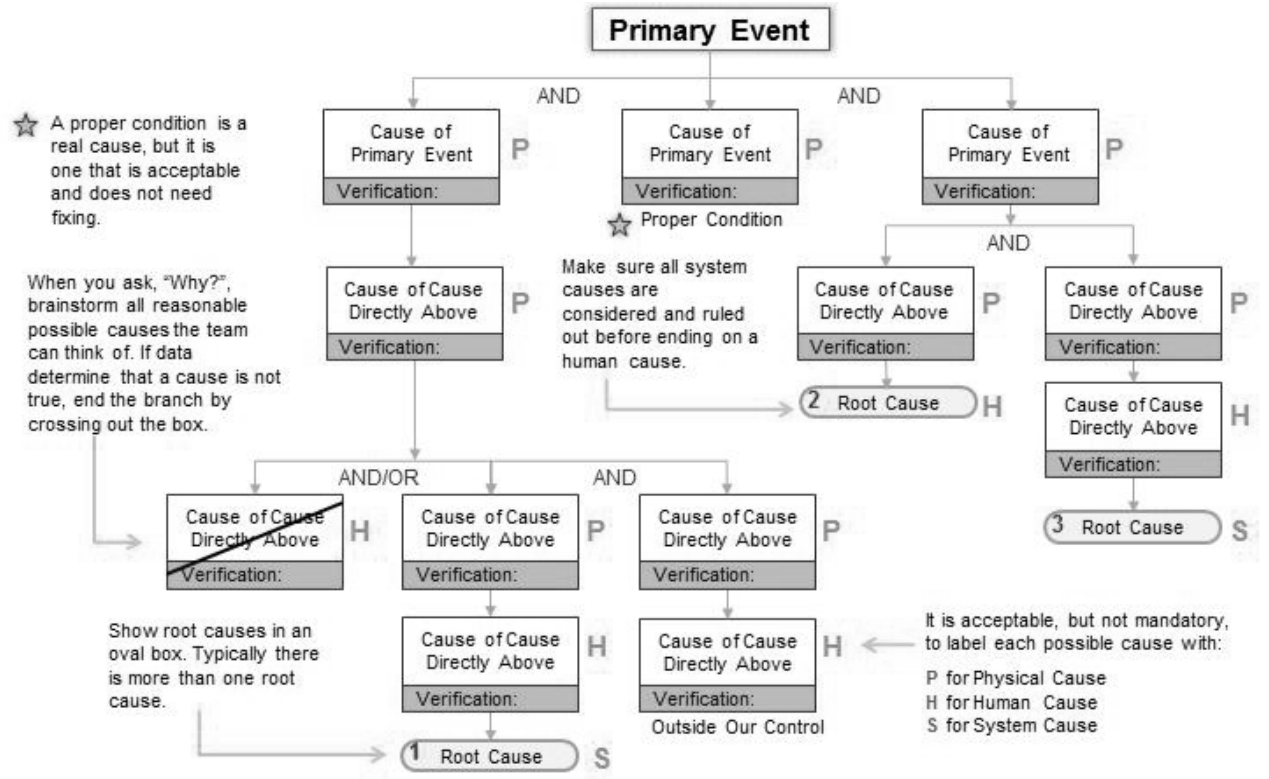

Figure 1. Schematic of a Why Tree with the various parts labelled

\section{Result and Discussion}

From the results of Why Tree analysis use RCA-Constructor software on Figure 2, there are several root causes in the form of "System cause", "Potential cause" as well as "Not true" and "Proper condition". Attention needs to be given to the root causes of the "System cause" and the "Potential cause". This root cause is identified as the basic cause of the occurrence of environmental problems. Verification of the RCA is done through reverse verification from bottom to the top of the Why Tree to ensure that the root causes are really and verified of the cause of the problem and if it is corrected, the event will not occur. 


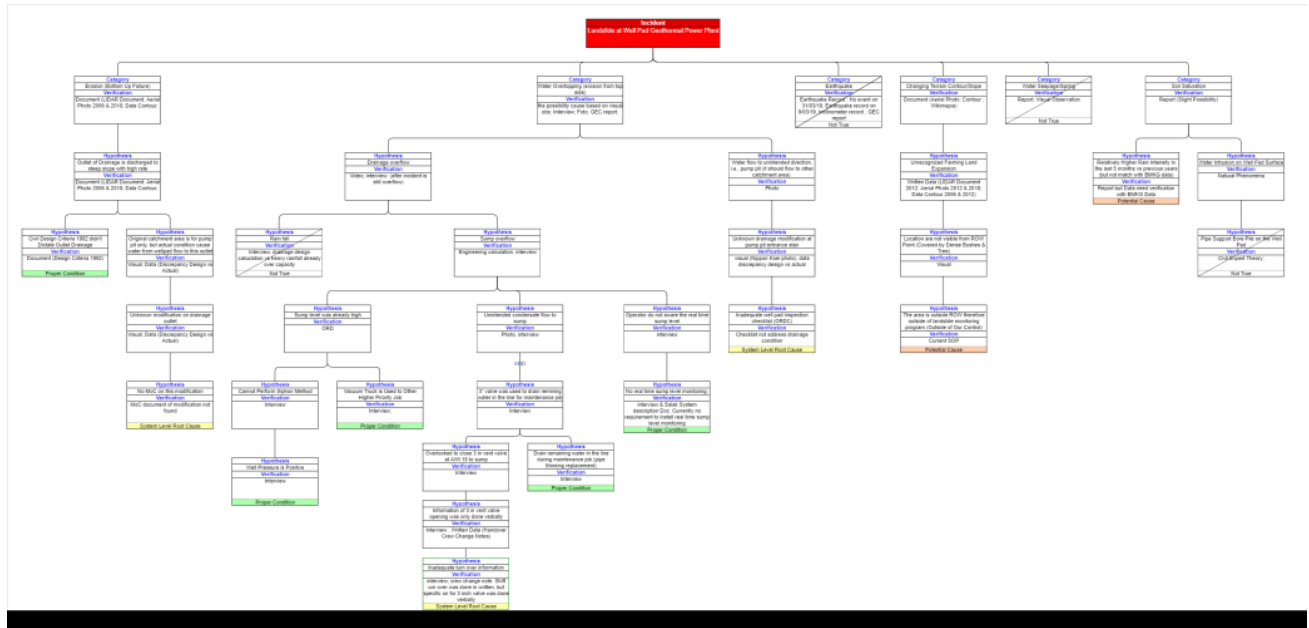

Figure 2. Result of Why Tree analysis using RCA-Builder software

The Table 2 shows that the identified root causes include (a) the absence of a management of change process in the change of drainage and (b) the absence of information during the officer shift exchange so the water flows out of the drainage towards the ground which causes erosion. Addition contributing cause is land expansion for agriculture that cause the slope of the cliff to be steeper and increases the risk of landslide.

Table 2. Physical cause and why tree analysis findings

\begin{tabular}{|l|l|l|l|}
\hline No & \multicolumn{1}{|c|}{ Physical cause } & Why Tree analysis findings & \multicolumn{1}{|c|}{ Consequence } \\
\hline 1 & $\begin{array}{l}\text { Erosion-water } \\
\text { discharge from } \\
\text { drainage directly to } \\
\text { steep slope on the } \\
\text { cliff. }\end{array}$ & $\begin{array}{l}\text { No Management of Change } \\
\text { (MoC) on the modification }\end{array}$ & $\begin{array}{l}\text { Erosion on the cliff } \\
\text { causes the steep angle of } \\
\text { the cliff. }\end{array}$ \\
\cline { 3 - 5 } & Earthquake & $\begin{array}{l}\text { Inadequate turnover } \\
\text { information }\end{array}$ & $\begin{array}{l}\text { Water flowing } \\
\text { continuously to the steep } \\
\text { slope. }\end{array}$ \\
\hline 3 & $\begin{array}{l}\text { Changing terrain } \\
\text { contour- } \\
\text { there was expansion } \\
\text { land clearing for } \\
\text { agriculture which is } \\
\text { expanding from year } \\
\text { to year so that it } \\
\text { changes the slope of } \\
\text { the terrain. }\end{array}$ & $\begin{array}{l}\text { Not true-there is no record } \\
\text { of an earthquake at the time } \\
\text { of the event }\end{array}$ & N/A \\
of control & $\begin{array}{l}\text { The terrain contour } \\
\text { becomes steeper. }\end{array}$ \\
\hline 4 & $\begin{array}{l}\text { Water spring on the } \\
\text { location }\end{array}$ & $\begin{array}{l}\text { Not true-There is no water } \\
\text { spring }\end{array}$ & N/A \\
\hline 5 & $\begin{array}{l}\text { Soil saturation } \\
\text { Not true-Moderate rainfall }\end{array}$ & N/A \\
\hline
\end{tabular}




\begin{tabular}{|l|l|l|l|}
\hline 6 & Manifest crater & $\begin{array}{l}\text { Not true-No new manifest } \\
\text { crater on site. }\end{array}$ & N/A \\
\hline
\end{tabular}

\section{Conclusion}

Root cause analysis using the Why Tree tool is very useful for investigating and finding the basic problems of an event that causes problems or impact to the environment. By correcting these underlying causes, it can be avoided that the same event will occur again later. Root cause in the investigation is the lowest level of causes that can be reasonable identified, if corrected, would prevent the incident from recurring and the organization has the control to fix.

Landslide cases investigated using the Why Tree method, system causes and potential causes can be found which are then verified back to ensure whether correcting the system cause and potential cause will not cause the primary event.

Prevention of reoccurring of similar type of accidents can be done thoroughly the investigating process and find the root causes and timely follow-up of the recommendations.

\section{References}

1. M. Imran Rashid, N. Ramzan, Q. Almasa, Wiley Online Library, Incident Investigation in Pakistan's Fertilizer Industry - Common Safety Management System Failures and Issues (2014)

2. Chevron, Incident Investigation Guidelines using WHY-TREE and 5-WHY Methods (2016)

3. United Nations, Sustainable Development Goals, URL : https://www.un.org/sustainabledevelopment/sustainable-development-goals/ (2018)

4. Rogers, Peter. P, An Introduction of Sustainable Development (London, Earthscan, 2008)

5. Badan Geologi ESDM, Pemutakhiran Basis Data Potensi Panas Bumi Indonesia, ESDM (2017)

6. R. Kaufmann, C. Cleveland, Mc Graw-Hill International, Environmental Science (2008).

7. A. Lubis, Jurnal Teknologi Lingkungan, Energi Terbarukan dalam Pembangunan Berkelanjutan (2007).

8. C. Sneddon, Ecological Economics 57, (2006).

9. W.P. Cunningham, Mc Graw-Hill-New York, Environmental Science a Global Concern (10th edition) (2008).

10. T. Miller, Boston: Cengage Learning, Environmental Science (2016).

11. W.C. Lucato, J.CdS.Santos, A. P. T. Pacchini, Sustainability 10, 81 (2018) doi:10.3390/su10010081

12. Forbes. K, Broadhead. J, Food and Agriculture Organization of the United Nations

Regional Office for Asia and the Pacific, Forests and landslides. The role of trees and forests in the prevention of landslides and rehabilitation of landslide-affected areas in Asia (2011). 